\title{
Review
}

\section{Politics, Theory, and Film: Critical Encounters with Lars von Trier}

\author{
Bonnie Honig and Lori J. Marso (eds.) \\ Oxford University Press, Oxford, 2016, xxiv+429pp., \\ ISBN: 9780190600174
}

Contemporary Political Theory (2018) 17, S1-S5. https://doi.org/10.1057/s41296-0170100-8; published online 20 February 2017

Lars von Trier is one of the most recognised and controversial filmmakers in the world. Academic study of his work, however, has only recently gained momentum, with a suite of volumes exploring questions of authenticity and artifice, modernism and auteurism, gender and politics. Bonnie Honig and Lori Marso's impressive interdisciplinary volume makes a significant contribution to this field, even if its approach to the question of politics in von Trier's oeuvre remains rather exploratory. The volume's contributors hail from the disciplines of film studies, politics, classics, religious studies, literary, historical, and media studies, with an accent on political theorists concerned with the relationship between aesthetics and politics. This makes for rich interdisciplinary inquiry but also leaves something wanting for readers looking for an explicitly political study of von Trier's provocative work.

Davide Panagia's Preface offers a contextualising articulation of the volume's central concerns: the productive parallels to be explored between cinema and politics, and the idea of a 'political cinematic thinking' (p. 12). Panagia means by this the manner in which cinema and politics both involve montage-like processes of community formation: the 'cut and paste' (p. 12) or synthesising of actions and perspectives involved in the 'creative assembly of worlds' (p. 16). Panagia's focus, moreover, is on the idea of politics as form: that the political significance of von Trier's films is to be found, not in its narrative contents but in its aesthetics of disruption, an idea familiar from the discourse of 'political modernism' in cinema. For Panagia, the link between cinema and politics takes on both a modernist (aesthetic revolution parallels social revolution) and a Deleuzian cast (cinematic thinking involves the invention of images that provoke the creation of concepts). Creative political cinematic thinking (and theorising), he claims, now amounts to 'a practice of invention and improvisation that allows us to imagine an affective constellation of worlds combining in aberrant forms' (p. 17). It remains unclear,

(c) 2017 Macmillan Publishers Ltd. 1470-8914 Contemporary Political Theory Vol. 17, S1, S1-S5 
however, whether this is the preserve of neomodernist auteurs like von Trier or a more general claim about cinema and politics.

Von Trier's subversive deployment of genre and cinematic cliché is ably explored in Honig and Marso's Introduction, 'Lars von Trier and the "Clichés of our Times"'. Reversing some of the media clichés about von Trier, they argue that his fascination with cliché provides the subject matter and target of his films. Indeed, intensifying clichés of gender, power, and politics in a manner that ironises them, they claim, 'may press democratic and feminist theory in new directions', perhaps liberating theorists from their own ennui (pp. 1-2). Von Trier's extraction of the 'truth' in clichés dealing with anti-Semitism, race relations, gender politics, and misogyny reveals him to be a 'thinker in cinema' (to use Thomas Elsaesser's phrase) whose cinematic provocations contest the ideological clichés of our age.

These two pieces are followed by a recent Danish interview with von Trier, where he explains his fascination with Judaism and shock at discovering, at his mother's deathbed, that his father was not Jewish but German. This interview is framed by video artist Tony Cokes' images of text fragments from von Trier's notorious 'Nazi' interview at Cannes (with later sections on David Bowie and Kanye West). The interdisciplinary credentials of the volume thus established, the chapters then track the best known films of von Trier's oeuvre, with essays on The Element of Crime (1984), Europa (1991), Breaking the Waves (1996), The Idiots (1998), Dancer in the Dark (2000), Dogville (2003), Manderlay (2005), Antichrist (2009), Melancholia (2011), and Nymphomaniac Volumes I and II (2013). Despite Panagia's claims to present a novel integration of political and cinematic analyses, the chapters fall into two camps: those that explore various aesthetic aspects of von Trier's work and those that focus on more explicitly ethical or political themes or topics.

The first cluster of essays tackles the most difficult topic in von Trier's oeuvre: the question of women, feminism, and misogyny. Lori J. Marso, inspired by de Beauvoir's essay, 'Must We Burn Sade?', challenges von Trier's alleged 'misogyny'. Through a close reading of Antichrist, she claims that his films expose, rather than endorse, the myths underpinning patriarchal discourse, showing these to be destructive dead ends but also suggesting the possibility of something beyond patriarchy. Focusing on Antichrist and Nymphomaniac, Rosalind Galt argues that the modes of spectatorial complicity provoked by his films demonstrate the entwining of cinema, sexuality, and the political by establishing a perversely 'destabilizing affective relationship with the spectator' (p. 72). The notorious BDSM scenes between Joe (Charlotte Gainsbourg) and K. (Jamie Bell) are allegories of this perverse relationship, with $\mathrm{K}$. standing in for the obsessive director and Joe for the suffering spectator (pp. 72 ff.). Lynne Huffer's 'The Nymph Shoots Back: Agamben and the Feel of the Agon' also focuses on Nymphomaniac, exploring the film's multi-layered allusions to Western artistic, scientific, theological, and cinematic history. According to her, the film's gendered structure 
and agonistic denouement-in particular Joe's shooting of Seligman (the director's stand-in, according to Huffer), against a self-negating black screen-suggests that it is an iconoclastic remake of 'the classic Pygmalion story' (p. 99), one offering a critical counterpoint to Giorgio Agamben's recent reflections on the relationship between (masculinist) artistic creativity and the (feminine) artistic image (p. 100).

Stephen S. Bush and James Martel both offer readings of Breaking the Waves. Bush challenges the 'goodness' interpretation (emphasising sacrificial love for the other), claiming that the film is a Bataillean exploration of violence that exposes our commonality with Bess as sacrificial victim, while acknowledging the pleasure we take in cruel and violent impulses. Martel explores fate and divine intervention in the film by examining the nature of Bess's belief, especially the peculiar relationship she has with (her) God, whom she both addresses and ventriloquises. Examining the paradoxes of Bess's (self-destructive) belief leads him to conclude that we are not self-determining subjects or autonomous agents, 'and, most important, not political' (p. 162)—a curious remark in the context of this volume.

Victoria Wohl tackles this relationship between the provocative politics and cinematic form in von Trier's films by analysing national (American) and individual fantasy in Dancer in the Dark. She explores the film's metaphorics of blindness and vision as ways of allegorising the ideological 'double vision' required to 'sustain the American dream and the blind spots produced by this effort' (p. 169). The film's 'double vision of its protagonist', Selma (Björk), who is at once a visible prop of individualist ideology and its unwitting victim, presents her as an ambiguous subject who 'exposes the political risks and possibilities of Dancer's subjective mode of filmmaking' (p. 170). Less persuasive is Paul Apostolidis's attempt to read Dogville in light of (but also against) Jacques Rancière's critical remarks on the 'ethical turn' in recent cinema away from radical politics (of which Dogville is an example, according to Rancière). Apostolidis takes the film, however, as thematising and critiquing (rather than exemplifying or embodying) this 'ethical turn', claiming that Dogville is 'a bleak representation of the dualistically shaped ethics in which leading public discourses today implicate the citizen-protectors of the national security state and its victims alike' (p. 192). At the same time, he claims that the film offers hints of a critical alternative to the status quo, 'inventive tactics'-both aesthetic and critical — to challenge moralistic social justice discourse and oppressive state power. Despite obvious references to Brechtian texts and staging techniques, Apostolidis eschews Brechtian political aesthetics in his approach, recruiting Dick Hebdige's work on subcultures to claim that Dogville offers a 'counterhegemonic politics of style that Rancière neglects' (pp. 192-193).

Elisabeth R. Anker tackles the problem of slavery in Manderlay, arguing that the film offers three versions of emancipation: de jure abolition, which fails to offer freedom or to end slavery; 'forced' emancipation from oppression (offered as a gift by the troubled Dogville character Grace (Bryce Dallas Howard)) that merely cultivates new forms of bondage; and emancipatory theft (Timothy's [Isaach De 
Bankolé] theft of the plantation's money, which he then gambles away), a 'liberatory' transgression that underscores how the theft of black bodies provided the foundation of slavery (pp. 218-219). In doing so, the film questions contemporary discourses concerning emancipation, Anker argues, emphasising the 'tragedy of contemporary racial politics without either calling for idealised performances of freedom or insisting on the inevitability of defeat' (p. 234).

A number of scholars have noted von Trier's deployment of rules, constraints, and game-playing. Lars Tønder takes up the topic in his analysis of The Idiots, focusing on the (Kierkegaardian) idea of 'comic rule following', which not only encourages an experiential approach to social rule breaking but emphasises its empowering effects and democratic potentials. Michael J. Shapiro submits von Trier's first feature film, The Element of Crime, to a Deleuzian reading, highlighting the role of the 'elements' - 'sand and water' and fire-as metaphors 'for the fundamental conditions in the film's cinematic geography', and as contributing to an aesthetic critique of the idea of Europe (p. 266, 280). The representation of Evil in Europa and Melancholia is explored by Joshua Foa Dienstag, who argues that both films focus on (male) characters that remain blind to evil and those (female) characters who see it (the 'werewolf perspective'), but that von Trier finally embraces artifice and illusion-contra the Dogme'95 manifesto advocating aesthetic abstinence-in order to represent cinematically political evil (Europa) and radical evil (Melancholia).

In a standout piece, Thomas Elsaesser elaborates his conception of mind-game films by analysing Melancholia as a (cinematic and philosophical) thought experiment, one that stages an ambiguous parallel between the 'end of the world' scenario and the 'end of cinema' topos. Elsaesser draws on the Deleuzian idea of cinematic thinking (through images that call forth concepts), and on recent work on the idea of 'film as philosophy', which treats films as " "strong texts", creating their own frames of reference' or as 'allegories of their own conditions of possibility' ( $p$. 309). Conceived as a 'what-if' scenario inviting multiple interpretations, and operating via a combination of 'undecidability' (regarding mood and texture) and 'reversibility' (in power relations), Elsaesser shows how three different interpretations of Melancholia - "“auteurist”, psychoanalytic, Foucauldian' (p. 314)— support his claim that it is both a philosophical 'thought experiment' and a 'mindgame' film, one responding to digital cinema's ambiguous challenges to the legacy of modernist cinephilia.

Miriam Leonard's and Bonnie Honig's contributions explore the surprising conjunction between classical tragedy and von Trier's films Medea and Melancholia. For Leonard, von Trier's video version of Euripides' classical tragedy (based on a script by Carl Theodor Dreyer) not only stages some of the paradoxes inherent in human action, but also offers a tragic political vision marked by a motivating relationship between melancholia and responsibility (p. 350). Honig recruits both Euripides' Bacchae and D.W. Winnicott's work on adolescence in her intriguing 
reading of Melancholia, which focuses not on the relationship between melancholic Justine and her caring sister Claire but rather on Claire's son, Leo, whose transition into adolescence is allegorised in the film's cataclysmic conclusion, von Trier's version of Winnicott's 'world-ending experience of adolescence' (p. 357). Not only Leo (the director's stand-in, according to Honig) but Justine and Claire too have difficulty acceding to their social roles, and seek to create (once the useless male characters are despatched) a reconfigured nuclear family in the 'magic cave' they construct just before planet Melancholia destroys the Earth. She concludes with the observation that Melancholia shares Euripides' interest in women's worship, amplifying the dimensions that have to do with 'youth, masculinity, and maturation', while downplaying the 'more overtly political dimensions', such as rebellion and sacrifice (p. 371). She even remarks that von Trier perhaps 'emphasizes the psychological at the expense of the political', but does not thereby displace politics altogether-Justine's isolation after refusing to play the neoliberal game leaving her 'forced to pay the price of world-endingness' (p. 373).

In a philosophical approach to Melancholia, Christopher Peterson uses the film, along with Cuáron's Gravity (2013), to launch a critique of speculative realism, targeting the excessive claims of 'object-oriented ontology'. On the one hand, the twin forces of 'gravity and melancholia' in both films direct our attention 'toward the nonhuman things that inhabit our world' and thereby question the privileged anthropocentric position of judgment in regard to nonhuman objects (p. 390). On the other hand, both films emphasise the ineluctably human horizon of our experience of such worlds, the unavoidable 'psychical Ptolemaism' that tempers the more hyperbolic claims of post-humanistic, object-oriented ontology. Finally, William E. Connolly also offers a brief meditation on Melancholia, touching on mortality, extinction, apocalypse, and the possibility of a theological, ethical, and inclusive (rather than exclusive) humanism that the film, however obliquely, suggests through images and mood.

This fascinating collection of thoughtful engagements with von Trier's provocative works breaks new ground in articulating their philosophical, aesthetic, and political significance. Nonetheless, the elusive relationship between cinematic aesthetics and a reconceived politics remains something of a promissory note, one that is felt and experienced on screen, linked to aesthetic innovation and moral provocation, but also difficult to conceptualise theoretically. This is why the critical dialogue with filmmakers such as von Trier needs to continue, a task admirably commenced by Honig and Marso's timely and welcome volume.

Robert Sinnerbrink Macquarie University, North Ryde, Sydney, NSW 2109, Australia 